\title{
Morphology of the zoeae larvae of Brachyura (Crustacea, Decapoda) in Veracruz, southwestern Gulf of Mexico
}

\author{
Sergio Cházaro-Olvera ${ }^{1, *}$, Ignacio Winfield Aguilar ${ }^{1}$, Manuel Ortiz Touzet ${ }^{1}$, \\ Horacio Vázquez-López ${ }^{1}$, Guillermo Javier Horta-Puga ${ }^{2}$ \\ ${ }^{1}$ Laboratorio de Crustáceos, Facultad de Estudios Superiores Iztacala, Universidad Nacional Autónoma de México. Av. de los Barrios \\ Numero 1, Los Reyes Iztacala, 54090 Tlalnepantla, Estado de México, México \\ ${ }^{2}$ UBIPRO, Facultad de Estudios Superiores Iztacala, Universidad Nacional Autónoma de México. Av. de los Barrios Numero 1, Los \\ Reyes Iztacala, 54090 Tlalnepantla, Estado de México, México
}

\section{Email address:}

chazaro@campus.iztacala.unam.mx(S.Cházaro-Olvera),ignacioc@unam.mx(I. W. Aguilar), ortiztouzet@yahoo.com(M. O.Touzet), hvazquez@campus.iztacala.unam.mx(H. Vázquez-López), horta@unam.mx(G. J. Horta-Puga)

\section{To cite this article:}

Sergio Cházaro-Olvera, Ignacio Winfield Aguilar, Manuel Ortiz Touzet, Horacio Vázquez-López, Guillermo Javier Horta-Puga. Morphology of the Zoeae Larvae of Brachyura (Crustacea, Decapoda) in Veracruz, Southwestern Gulf of Mexico. American Journal of Life Sciences. Vol. 1, No. 5, 2013, pp. 238-242. doi: 10.11648/j.ajls.20130105.16

\begin{abstract}
Larval zoeae of Brachyura were collected from five coastal systems located in the State of Veracruz, southwestern Gulf of Mexico. Some morphological differences among the zoeae families have been determined. Morphological analysis consisted of the following determinations: presence of rostral spines, dorsal and lateral, on the carapace; number of setae of the exopod, endopod, and protopod of the antenna; number of processes; shape and size of the somites of the abdomen; and the presence and number of spines on the furcae and inner margin of thetelson. A total of 92839 zoeae of Brachyura were obtained, and 14 families were identified: Aethridae, Calappidae, Portunidae, Menippidae, Panopeidae, Gecarcinidae, Grapsidae, Sesarmidae, Varunidae, Inachidae, Epialtidae, Pinnotheridae, Ocypodidae, and Ucididae. Morphological differences between these families include: Epialtidae and Inachidae lack lateral spines; Pinnotheridae lacks spines on one side of the carapace, and there may be a wing shape on the fifth abdominal somite; the exopod of the antenna is short in Grapsidae and well-developed in Ucididae; the fourth abdominal somite is significantly expanded in Ocypodidae; the family Gecarcinidae lacks spines on the furcae; Portunidae, Calappidae, and Aethridae have two or three spines on the furcae, but differ in the size of the exopod of the antenna relative to the size of the rostrum; and Sesarmidae and Varunidae differ in the lateral spines on the carapace. A key for identification of the zoeae to the family level is presented.This is the first key for Brachyura zoeae from the southwestern Gulf of Mexico.
\end{abstract}

Keywords: Crustacea, Brachyura, Zoeae, Key Identification, Gulf of Mexico

\section{Introduction}

The order Decapoda Latreille, 1802 is represented by 374 species in Veracruz, southwestern Gulf of Mexico. Of these, $77.8 \%$ are marine species; $8.5 \%$, estuarine; $10.4 \%$, freshwater; and $3.2 \%$, semiterrestrial. About 160 of these Decapoda species belong to the infraorder Brachyura $[1,2]$. During larval development, some species of the infraorder may have a protozoea stage, two or more stages of zoea, and a megalopa stage [3]. Decapod larvae are typically present in coastal zones, estuaries, and rivers as a result of their migratory behavior [1].

For many years, brachyuran zoeae have been identified using the descriptions provided by Reference [4], [5], and
Reference [6]. More recently, there have been descriptions by Reference [7, 8, 9, 10, 11, 12, 3] and Reference [13].

Only one study has described the megalopae of the Panopeidae family in the southwestern Gulf of Mexico [14]. The goals of the present study were to contribute to the knowledge of the morphology of brachyuran zoeae found in Veracruz and develop a key for the identification of those zoeae.

\section{Materials and Methods}

Zoeae were collected from five coastal systems in Veracruz, southwestern Gulf of Mexico, $18^{\circ} 52^{\prime}$ to $20^{\circ} 08^{\prime} \mathrm{N}$ 
and $95^{\circ} 42^{\prime}$ to $97^{\circ} 18^{\prime} \mathrm{W}$ (Fig. 1). We considered the species list developed by Reference [1] and collections created as parts of different projects deposited in the Laboratory of Crustaceans of FES Iztacala, UNAM (LCFESI) between 1995 and 2012. Ovigerous females of some species were collected directly and transported to LCFESI in order to follow the development of the larvae. Biological material was collected with a conical net $(1.0 \mathrm{~m}$ length, $0.75 \mathrm{~m}$ width, and $243 \mu \mathrm{m}$ mesh aperture). The material was fixed in $70 \%$ ethanol solution, inserted in plastic containers, and transferred to LCFESI.

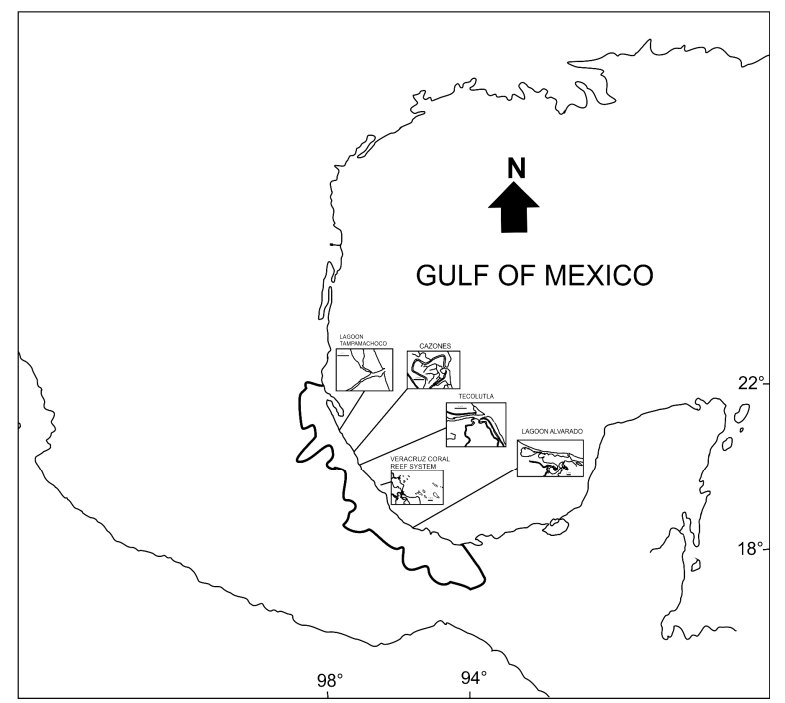

Figure 1.Veracruz Coastal System sampled in the southwestern Gulf of Mexico

Morphological analysis consisted of the following determinations: presence of rostral spines, dorsal and lateral, on the carapace; number of setae of the exopod, endopod, and protopod of the antenna; number of processes; shape and size of the somites of the abdomen; and the presence and number of spines on the furcae and inner margin of the telson. Pre-identification of zoeae was conducted using the original descriptions by Reference [15], [16], [17], [18], [19], [20], [21], [22], [11], [23], [24], [25] and Reference [26]. Diagrams were prepared using a Leica DM750 microscope equipped with a digital camera with 1.3 Moticam 1SPMP and Corel Draw X6 version 16.0.0 program 707.

\section{Results}

A total of 92,839 zoeae of Brachyura were obtained, and 14 families were identified: Aethridae Dana, 1851; Calappidae De Haan, 1833; Portunidae Rafinesque, 1815; Menippidae Ortmann, 1893; Panopeidae Ortmann, 1833; Gecarcinidae MacLeay, 1838; Grapsidae MacLeay, 1838; Sesarmidae Dana, 1851; Varunidae, H. Milne Edwards, 1853; Inachidae MacLeay, 1838; Epialtidae MacLeay, 1838; Pinnotheridae De Haan, 1833; Ocypodidae Rafinesque, 1815 and Ucididae Števčić, 2005.

Key to the families of Brachyura in the zoea stage in the southwestern Gulf of Mexico

1 a. Carapace with rostral, dorsal, and lateral spines ... 6

1 b. Carapace with no rostral, dorsal, or lateral spines ...2

2 a. Carapace with no rostral, dorsal, and lateral spines.. .......... Pinnotheridae (in part-Zaopsostreum, Fig. 2 C)

2 b. Carapace with rostral and dorsal spines, but without lateral spines, antenna usually developed, elongated telson furcae ....

3 a. Carapace with a projection, rostral spine reduced, dorsolateral processes in the second and third abdominal somite .............................. Inachidae (Fig. 2 A)

3 b. Carapace without projections .................. 4

4 a. Rostral spine shorter than the antennae; dorsolateral processes only in the second abdominal somite. Epialtidae (Fig. 2 B)

4 b. Rostral spine longer than antennae .............. 5

5 a. Exopod of the antenna short, endopod rudimentary Grapsidae (Fig. 2 E)

$5 \mathrm{~b}$. Exopod of the antenna well-developed and longer than half of the protopod length. Lateral spine of the carapace absent ........................Ucididae (Fig. 2 H, I)

6 a. Abdomen laterally and/or caudally expanded on some somites ...................................... 7

$6 \mathrm{~b}$. Abdomen with more or less parallel sides and short posterolateral spines on somites ........................ 8

7 a. Exopod of the antenna reduced like setae or absent; abdominal somite 5 laterally expanded in a wing-like shape Pinnotheridae (Austinixa reduced)

7 b. Antennal exopod setae not reduced, but less than one-half the length of the spinous process; abdominal somite 5 without wing shape; abdominal somite 4 significantly expanded

. Ocypodidae (Ocypode quadrata, Fig. 2 F, G)

8 a. No spines present on the furca of the Telson ........ 9

$8 \mathrm{~b}$. Spines present on the furca of the Telson ......... 10

9 a. Antenna exopod well-developed, about threequarters of the length of the spinous process; protopod well-developed ...................Gecarcinidae (Fig. 3 A, B)

$9 \mathrm{~b}$. Antenna with short exopod, endopod length one-half of protopod length ................................ 13

10 a. Telson usually with 2 or 3 spines on each furca; antennal exopod one-half the length of the protopod or shorter................................................. 11

$10 \mathrm{~b}$. Telson usually with a single spine on each furca; spinous process of the antenna of the same length from the rostral spine; exopod length one-quarter of the length of the spinous process; endopod length one-quarter of the length of the exopod; abdomen with dorsolateral spinous process on the second and third somites ......................... 12

11 a. Carapace with lateral spines short, one-third of the carapace width; exopod of the antenna very short, with spinous process one-quarter of the length of the rostral spine ..........................Portunidae (Figs. 3 D, E)

11 b. Carapace with lateral spines long, one-half the width of the carapace; antenna exopod one-quarter of the length of the spinous process Aethridae and Calappidae (Figs. 3 F, G) 
12 a. Antennal exopod approximately one-half to threequarters of the protopod length

Menippidae (Fig. 3 H, I)

12 b. Antennal exopod absent, reduced, or less than onequarter of the protopod length. Panopeidae (Fig. 3 C)

13a. Lateral spines absent from carapace Sesarmidae (Fig. 4 A, C)

13 a. Lateral spines present from carapace. Vanuridae (Fig. 4 D)
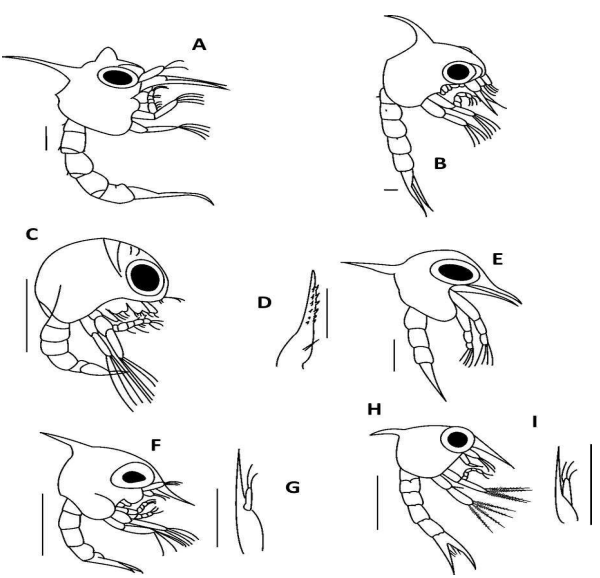

Figure 2. Brachyura zoeas. A, family Inachidae, Stenorhynchus seticornis (Herbst, 1788) zoea 1; B, family Epialtidae, Libiniadubia H. MilneEdwards, 1878, zoea 1; C, family Pinnotheridae, Zaopsostreum Say, 1817, zoea 1; D, family Grapsidae, Grapsus grapsus(Linnaeus, 1758), antenna, E, zoea 1; F, family Ocypodidae, Ocypode quadrata (Fabricius, 1787) antenna, G, zoea 1; H, family Ucididae, Uca burgersi Holthuis, 1967, zoea I, antenna. Scales: $A=0.2 \mathrm{~mm} ; B, D, F=0.1 \mathrm{~mm} ; C, E, G=0.5 \mathrm{~mm} . A$, modified of Reference [20]; $B$, modified of Reference [18]; $C$, modified of Reference [11]; D-E, modified of Reference [26]; F-G, modified of Reference [19]; H-I, modified of Reference [24].

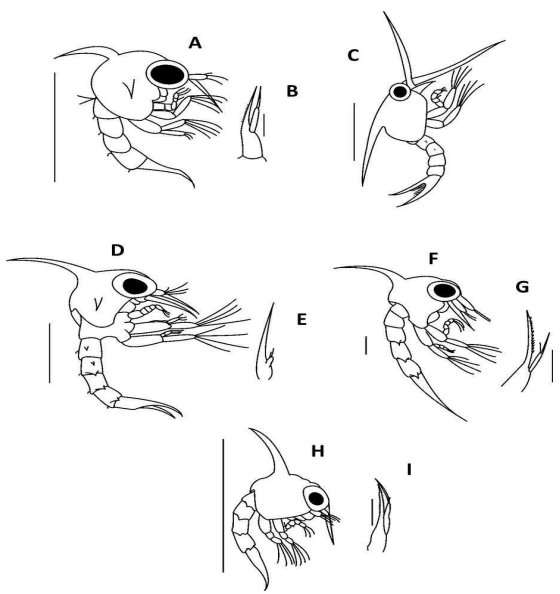

Figure 3. Brachyura zoeas. A, family Gecarcinidae, Gecarcinus lateralis (Freminville, 1835), antena B, zoea 1; C, family Panopeidae, Panopeus bermudensis Benedict and Rathbun, 1891 zoea 1; D, family Portunidae, Arenaeus cribrarius (Lamarck, 1818), zoea 1, E, antenna; F, family Aethridae, Hepatus epheliticus (Linnaeus, 1763), zoea 1, G antena; H, family Menippidae, Menippe mercenaria (Say, 1818), zoea 1, I, antenna. Scales: $A, D=0.1 \mathrm{~mm} ; B, I=1 \mathrm{~mm} ; C=0.5 ; E=0.4 \mathrm{~mm} ; \mathrm{F}, 0.2 \mathrm{~mm} ; G$, $H, J=0.1 \mathrm{~mm}$. A-B modified of Reference [21]; $C$, modified of Reference [22]; D-E, modified of Reference [23]; F-G, modified of Reference [15]; H-I modified of Reference [11].

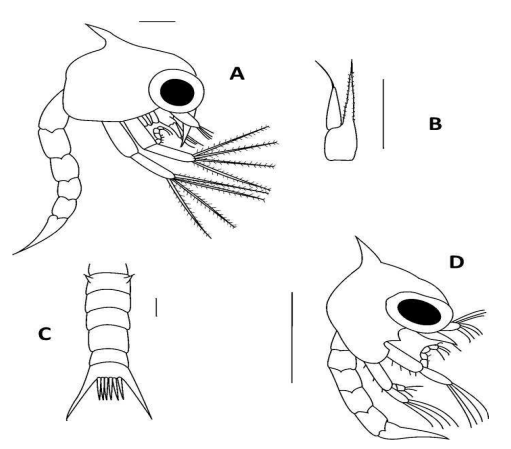

Figure 4. Brachyura zoeas.A, family Sesarmidae, Aratus pisonii (H. Milne-Edwards 1837), zoea 1, lateral view, $B$, antenna, $C$, abdomen and telson. D, family Vanuridae, Cyclograpsus integer H. Milne Edwards, 1837, zoea 1, lateral view. Scales: $A-C=0.1 \mathrm{~mm}, D=0.5 \mathrm{~mm} . A-C$ modified of Reference [17]; D, modified of Reference [11].

\section{Discussion}

Reference [1] reported 12 families of brachyuran crustaceans from the coast of the state of Veracruz; however, in the present study, the species list was arranged according to the classification proposed by Reference [27], which included 14 families belonging to the infraorder Brachyura.

In particular, species of the family Portunidae and Calappidae are distinguished primarily by the length and ornamentation of the rostral spine. According to Reference [23], the zoea of species in the family Portunidae have distinctive features, such as length of the antennal exopod relative to protopod length, number of aesthetascs on the antennula, and the number of setae on the scaphognathite of the maxilla, as presented in the detailed key.

The Panopeidae and Menippidae families have been described mainly by similarities between member species. Panopeus lacustris Desbonne, 1867; Panopeus herbstii H. Milne Edwards, 1834; Panopeus americanum Saussure, 1857; Panopeus austrobesus Williams, 1983; Panopeus africanus A. Milne-Edwards, 1867; Panopeus occidentalis Saussure, 1857; and Panopeus meridionalis Williams, 1983; are similar to species in the present study that have welldeveloped dorsal and rostral spines, antennal protopods that are as long as the rostral spine, exopods reduced to one seta, spines on the posterodorsales of the third to fifth abdominal somites, and telson with a spine on the outer surface of the furca [28]. Reference [29] argue that the zoeae of $P$. herbstii are differentiated from those of Eurypanopeus depressus Smith, 1869 by the presence of chromatophores on the antennae of E. depressus. Reference [30] also indicated that the zoea of Eurytium limosum Say, 1818 is characterized by a long antenna with a reduced exopod.

Classical authors, such as Reference [16], observed that the larvae of Cardisoma guanhumi Latreille, 1825 in the family Gecarcinidae have lateral spines on the second and third abdominal segments, which are similar to those of Gecarcinus lateralis, Fréminville, 1835. In this study, we found that these species are differentiated by the presence of two terminal and subterminal setae on the endopod of the 
maxilla and 12 setae on the protopod in G. lateralis, while $C$. guanhumi has three terminal and two subterminal setae on the endopod of the maxilla and 18 setae on the protopod.

The families Grapsidae, Sesarmidae, Vanuridae, differ in the length of the exopod of the antenna [31]. In this study, we found that these species are differentiated also by the presence or absence of lateral spines on carapace.

The majid families Epialtidae and Inachidae differ in the length of the spine and the processes of the second and third abdominal somite. Reference [18] documented the presence of long plumose setae on the ventral margin of the carapace that is characteristic of the zoeae of majids. We observed these plumose setae in the zoeae collected as part of the present study.

The species of the family Pinnotheridae are separated, in part, by the absence of spines on the carapace of some species, such as Zaopsostreum Say, 1817, and by the development and ornamentation of the antenna, carapace, and abdominal somites in other species, such as Austinixa cristata Rathbun, 1900 or Tumidotheres maculatus Say, 1818.

In the Ucididae and Ocypodidae families, we found that $O$. quadrata can be identified by the presence of lateral spines on the carapace that are not found in Uca and Ucides.

Finally, it is important to mention that this key represents the first such key prepared for the identification zoeae larvae in Mexico.

\section{Acknowledgements}

We appreciate the participation of students from the Facultad de Estudios Superiores Iztacala, PAPCA-20092010, PAPIIT UNAMIN229011, Veracruz Coral Reef System National Park administration, Secretary of Navy and Miguel Angel Lozano-Aburto of the Institute of Ecology and Fisheries(UV) for their support to this study.

\section{References}

[1] F. Álvarez, J. L. Villalobos and R. Robles, "Listas y comentarios sobre los crustáceos decápodos de Veracruz", Anales del Instituto de Biología, vol. 70 (1), pp. 127,1999 .

[2] F. Álvarez-Noguera, J. L. Villalobos and S. Cházaro-Olvera, "Camarones y cangrejos dulceacuícolas y marinos (Crustacea: Decapoda)", In: La biodiversidad en Veracruz, estudio de estado, diversidad de especies: conocimiento actual, A. Cruz-Angón, F. G. Lorea-Hernández, V. Hernández-Ortiz y J. E. Morales-Mavil, CONABIO, Universidad Veracruzana, Instituto de Ecología, A. C., Pp. p287-293, 2011.

[3] D. Pessani, T. Tirelli and S. Flagella, "Key for the identification of mediterranean brachyuran megalopae", Mediterranean Marine Science, vol. 5(2), pp. 53-64, 2004.

[4] M. V. Lebour, "The larval stages of the Plymouth Brachyura", Proceedings of the Zoological Society of London, vol. 98(2), pp. 473-560, 1928.
[5] R. Gurney, Larvae of decapod crustacean, London Royal Society, pp. 1- 306, 1942.

[6] L. Bourdillon-Casanova, "Le meroplancton du Golfe de Marseille: Les larves de Crustaces Decapodes", Recueil des Travaux de la Station Marined'Endoume, vol. 30(18), pp. 1$268,1960$.

[7] S. D. Salman, "Larval development of the crab Pilumnus hirtellus (L.) reared in the laboratory (Decapoda, Brachyura, Xanthidae)", Crustaceana, vol. 42, pp. 113-126, 1982.

[8] J. W. Martin, "Notes and bibliography on the larvae of xanthid crabs, with a key to the known zoeas of the western Atlantic and Gulf of Mexico", Bulletin of Marine Science, vol. 34, pp. 220-239, 1984.

[9] R. W. Ingle, Larval Stages of Northeastern Atlantic crabs. An Illustrated Key. Natural History Museum Publication and Chapman \& Hall, London, pp. 1-363, 1992.

[10] J. Paula, "A key and bibliography for the identification of zoeal stages of brachyuran crabs (Crustacea, Decapoda, Brachyura) from the Atlantic coast of Europe", Journal of Plankton Research, vol. 18, pp. 17-27, 1996.

[11] D. Boltovskoy, "South Atlantic zooplankton", Backhuys Publishers, Leiden, pp. 1-1706, 1999.

[12] S. G. Bullard (Ed) Larvae of anomuran and brachyuran crabs of North Carolina: A guide to the described larval stages of anomuran (Families Porcellanidae, Albuneidae, and Hippidae) and brachyuran crabs of North Carolina, U. S. A. Leiden, The Netherlands, Brill, pp. 1-142, 2003.

[13] J. Medellín-Mora, N. H. Campos, A. Franco-Herrera and J. C. Jaimes, "Taxonomía de larvas zoea de crustáceos decápodos del área nororiental del mar Caribe Colombiano", Boletín de Investigaciones Marinas y Costeras, vol. 38, pp. $55-73,2009$.

[14] S. Cházaro-Olvera, A. Rocha-Ramírez and H. VázquezLópez, "Morphological differentiation of megalopae in the family Panopeidae Ortmann, 1893, from a lagoon system inlet in the southwestern Gulf of Mexico", Crustaceana, vol. 79(7), pp. 865-878, 2006.

[15] J. D. Costlow Jr. and C. G. Bookhout, "The larval development of Hepatus epheliticus (L.) under laboratory conditions", Journal of the Elisha Mitchell Scientific Society, vol. 78, pp. 113-125, 1962.

[16] J. D. Costlow Jr. and C. G. Bookhout, "Larval development of the land-Crab, Cardisoma guanhumi Latreille in the Laboratory (Brachyura, Gecarcinidae)", Crustaceana, (Supplement 2), pp. 259-270, 1968.

[17] G. F. Warner, "Development of the mangrove tree crab, Aratus pisonii (H. Milne Edwards), reared in the laboratory (Brachyura, Grapsidae)", Crustaceana, (supplement 2), pp. 249-258, 1968.

[18] P. A. Sandifer and W. A. van Engel, "Larval development of the spider crab Libiniadubia H. Milne-Edwards (Brachyura, Majidae, Pisinae), reared in laboratory culture", Chesapeake Science, vol. 12, pp. 18-25, 1971.

[19] H. Díaz and J. D. Costlow, "Larval development of Ocypode quadrata (Brachyura: Crustacea) under laboratory conditions", Marine Biology, vol. 15, pp. 120-131, 1972. 
[20] W. T. Yang, "Studies on the western Atlantic arrow crab genus Stenorhynchus (Decapod brachyuran, Majidae) I. Larval characters of two species and comparison with other larvae of Inachinae", Crustaceana, vol. 31(2), pp. 157-177, 1976.

[21] K. A. Willems, "Larval development of the land crab Gecarcinus lateralis lateralis (Fréminville, 1835) (Brachyura, Gecarcinidae) reared in the laboratory", Journal of Crustacean Biology, vol. 2(2), pp.180-201, 1982.

[22] J. W. Martin, F. M. Truesdaleand and D. L. Felder, "Larval development of Panopeu sbermudensis Benedict and Rathbun, 1891 (Brachyura, Xanthidae) with notes on zoeal characters in xanthid crabs", Journal of Crustacean Biology, vol. 5(1), pp. 84-105, 1985 .

[23] K. Stuck and F. Truesdale, "Larval development of the speckled swimming crab, Arenaeu scribrarius (Decapoda: Brachyura: Portunidae) reared in the laboratory", Bulletin of Marine Science, vol. 42(1), pp. 101-132, 1988.

[24] R. P. Juárez, "Desenvolvimento larval de Uca (Minuca) burgers Holthuis (Crustacea, Decapoda, Ocypodidae), em laboratorio", Revista Brasileira de Zoologia, Vol. 15(3), pp. 727-756, 1998

[25] J. A. Cuesta and C. D. Schubart, "First zoeal stages of Geograpsus lividus and Goniopsis pulchra from Panama confirm consistent larval characters for the subfamily Grapsidae (Crustacea: Brachyura: Grapsidae)", Ophelia, vol. 51(3), pp. 163-176, 1999.
[26] G. Guerao, C. D. Schubart and J. A. Cuesta, "The first zoeal stage of Grapsus grapsus L. and Geograpsus lividus (H. Milne Edwards) (Decapoda, Brachyura, Grapsidae) from the western Atlantic", Nauplius, vol. 9(2), pp. 111-121, 2001.

[27] P. K. L. Ng, D. Guinot and P. J. F. Davie, "System Brachyurorum: Part I. An Annotated checklist of extant brachyuran crabs of the world", Raffles Bulletin of Zoology, (supplement 17), pp. 1-286, 2008.

[28] A. S. de Souza, R. M. da Costa and F. A. Abrunhosa, "The complete larval development of Panopeus lacustris Desbonne 1867 (Brachyura: Panopeidae), from the Amazon region, reared in the laboratory", Acta Zoologica (Stockholm), vol. 94, pp. 308-323, 2013.

[29] J. D. Costlow Jr and C. G. Bookhout, "The larval stages of Panopeus herbstii Milne Edwards reared in the laboratory", Journal of the Elisha Mitchell Scientific Society, vol. 77(1), pp. 33-42, 1961.

[30] H. Kurata, R. W. Heard and J. W. Martin, "Larval development under laboratory conditions of the xanthid mud crab Eurytium limosum (Say, 1818) (Brachyura: Xanthidae) from Georgia", Gulf Research Reports, vol. 7(1), pp. 19-25, 1981.

[31] H. Aikawa, "On larval forms some Brachyura", Records Oceanographic Works in Japan, vol. 2(1), pp. 17-55, 1929. 